\title{
PENINGKATAN AKTIVITAS BELAJAR SISWA MELALUI MODEL PEMBELAJARAN TALKING STICK PADA MATA PELAJARAN IPS DI SMP NEGERI 02 RANAH PESISIR
}

\author{
Syamsiwarni \\ Guru Mata Pelajaran IPS pada SMPN 2 Ranah Pesisir, Kabupaten Pesisir Selatan \\ syamsi_warni02@gmail.com
}

\begin{abstract}
This study tried to proof if the use of Talking Stick learning model could improve student activities in Social Science subject matter in SMPN 2 Ranah Pesisir. This study was a classroom action research conducted at grade VIII 2 SMPN 2 Ranah Pesisir in the first semester of Academic Year of 2012/2013 with a population consisted of 34 students. This study was conducted in two cycles. Each cycle was carried out with three meetings. From the results of the study it could be concluded that there was a significant increase in students' activities using Talking Stick learning model. By applying this model, students' activities increased. In addition, they were more motivated to learn because they thought this model was interesting and fun. The results of this study showed the increasing of Social Science learning activities after the implementation of cooperative learning with Talking Stick model. It means that the Talking Stick model could improve student learning activities in Social Science subject at grade VIII 2 SMPN 2 Ranah Pesisir.
\end{abstract}

Keywords: Learning activities, Social Science, Talking Stick model

How to Cite: Fatmaliza, Syamsir, dan Jumiati. 2018. Peningkatan Aktivitas Belajar Siswa Melalui Model Pembelajaran Talking Stick Pada Mata Pelajaran IPS di SMP Negeri 02 Ranah Pesisir. 2(2): pp. 125-135. DOI: https://doi.org/10.24036/jess/vol2-iss2

\section{Pendahuluan}

Pembelajaran moderen berupaya mengembangkan proses yang berorientasi pada peserta didik atau Kurikulum Tingkat Satuan Pendidikan (KTSP) yaitu kurikulum operasional yang disusun dan dilaksanakan oleh masing-masing satuan pendidikan/sekolah yang disosialisasikan pada tahun 2006. Hal ini juga harus ditunjang dengan penggunaan model mengajar yang mendukung terlaksananya KTSP tesebut. Model pembelajaran yang direncanakan tersebut terus dapat mendukung hasil belajar secara optimal. Menurut Surachmat (dalam Nashihin, 2005) hasil belajar sebagai tujuan belajar tidak boleh lepas dari pengumpulan pengetahuan, penemuan konsep, dan kecekatan, serta pembentukan sikap dan perbuatan.

Aktivitas siswa di kelas sangat tergantung kepada pendidik yang memberikan pelajaran. Peserta didik akan beraktivitas dengan baik apabila pendidik mengelola pembelajaran secara profesional. Salah satu usaha pendidik untuk meningkatkan aktivitas belajar siswa adalah dengan menggunakan model belajar yang baik dan tepat dalam mengajar. Pendidik tidak harus terpaku pada 
satu model pembelajaran saja tetapi harus menggunakan model yang bervariasi agar pembelajaran IPS tidak membosankan peserta didik. Pendidik harus mampu memilih model mengajar yang dapat melibatkan peserta didik secara optimal sehingga peserta didik menjadi aktif dan berfikir kritis sehingga kreativitasnya dapat berkembang.

Berdasarkan pengamatan yang penulis lakukan pada Kelas VIII.2 SMPN 02 Ranah Pesisir Kabupaten Pesisir Selatan dan wawancara dengan guru bidang studi IPS terindikasi bahwa pada proses pembelajaran, guru mengeluhkan tidak terjadinya proses pembelajaran yang diharapkan karena siswanya kurang aktif atau rendahnya keterlibatan siswa dalam pembelajaran sehingga dalam pelaksanaan pembelajaran suasana dan kelas terlihat monoton. Secara garis besar dalam pelaksanaan proses pembelajaran di Kelas VIII.2 SMPN 02 Ranah Pesisir Kabupaten Pesisir Selatan ada beberapa kenyataan yang ditemukan sebagai berikut:

1. Siswa kurang aktif dalam pembelajaran; dan hal ini dapat dilihat dari aktivitas siswa seperti mendengar dan membaca sangat sedikit dalam proses pembelajaran,

2. Perhatian peserta didik terhadap pelajaran yang diberikan oleh pendidik (guru) sangat kurang,

3. Jumlah siswa yang mengacungkan tangan, menjawab, memberikan pendapat, dan bertanya dalam proses pembelajaran sangat sedikit. Gambaran tentang hal ini dapat dilihat Pada Tabel 1 berikut ini:

Tabel 1. Aktivitas Siswa Saat Proses Pembelajaran

\begin{tabular}{clccc}
\hline No & \multicolumn{1}{c}{ Aktivitas Siswa } & \multicolumn{2}{c}{ Siswa Yang Aktif } & $\begin{array}{c}\text { Jumlah } \\
\text { Seluruh } \\
\text { Siswa }\end{array}$ \\
\cline { 2 - 3 } 1. & $\begin{array}{l}\text { Aktivitas mendengarkan waktu guru } \\
\text { menerangkan }\end{array}$ & 17 & 50 & 34 \\
2. $\begin{array}{l}\text { Aktivitas membaca ketika diberi kesempatan } \\
\text { membaca }\end{array}$ & 10 & 29 & 34 \\
3. $\begin{array}{l}\text { Aktivitas mengacungkan tangan saat guru } \\
\text { memberi pertanyaan }\end{array}$ & 2 & 6 & 34 \\
4. $\begin{array}{l}\text { Aktivitas memberikan jawaban ketika guru } \\
\text { memberikan pertanyaan }\end{array}$ & 3 & 9 & 34 \\
5. Aktivitas memberikan pendapat ketika diberi & $\begin{array}{l}\text { kesempatan mengeluarkan pendapat } \\
\text { Aktivitas bertanya ketika diberi kesempatan } \\
\text { bertanya }\end{array}$ & - & - & 34 \\
\hline
\end{tabular}

Sumber: Pengolahan Data Primer

Banyak siswa yang belum tuntas dalam belajar dan banyak siswa yang belum menguasai pelajaran secara optimal karena aktivitasnya yang rendah.

Hasil renungan dan diskusi dengan teman sejawat menyimpulkan bahwa permasalahan di atas muncul karena beberapa faktor antara lain: (1) kurangnya minat siswa terhadap pelajaran IPS, (2) rendahnya keberanian siswa untuk 
bertanya dan mengeluarkan pendapat, (3) kuatnya peranan guru dalam pembelajaran. Faktor tersebut menyebabkan proses pembelajaran kurang menggairahkan.

Solusi yang direncanakan untuk mengatasi permasalahan tersebut adalah dengan menggunakan model pembelajaran Talking Stick Model pembelajaran ini dapat melibatkan peserta didik secara aktif dalam pembelajaran. Model ini diperkirakan akan dapat mendorong peserta didik untuk dapat aktif dan kritis karena menuntut siswa untuk lebih banyak membaca, bertanya dan memperhatikan guru waktu menjelaskan materi supaya bisa menjawab pertanyaan yang diberikan pendidik. Talking stick merupakan model pembelajaran yang berbentuk game/permainan. Bentuk permainannya adalah pada waktu stick (tingkat) diestafetkan dan berhenti saat hitungan dihentikan peserta didik harus menjawab pertanyaan dari pendidik. Hal ini akan membuat peserta didik lebih terpancing untuk membaca, bertanya dan memperhatikan pendidik waktu menerangkan materi. Apalagi setiap peserta didik yang bisa menjawab pertanyaan akan mendapatkan poin atau nilai. Disinilah menariknya model pembelajaran talking stick yang bisa membuat siswa lebih semangat belajar.

Bertolak dari hal tersebut peneliti tertarik untuk melakukan penelitian tindaka kelas dengan judul "Peningkatan Aktivitas Belajar Siswa Melalui Model Pembelajaran Talking Stick pada Mata Pelajaran IPS pada Siswa Kelas VIII.2 SMPN 02 Ranah Pesisir Kabupaten Pesisir Selatan. Penelitian ini ingin membuktikan apakah pendekatan pembelajaran dengan menggunakan model Talking Stick mampu meningkatkan aktivitas belajar siswa (mendengarkan, membaca, mengacungkan tangan, memberikan jawaban, memberikan pendapat dan bertanya) dalam mata pelajaran IPS siswa Kelas VIII.2 SMPN 02 Ranah Pesisir Kabupaten Pesisir Selatan?

\section{Tinjauan Kepustakaan}

\section{Aktivitas Belajar}

Menurut Mulyono (2001), aktivitas artinya kegiatan/keaktifan. Jadi segala sesuatu yang dilakukan atau kegiatan-kegiatan yang terjadi baik fisik maupun non-fisik, merupakan suatu aktifitas. Pengajaran yang efektif adalah pengajaran yang menyediakan kesempatan belajar sendiri atau melakukan aktivitas sendiri. Pada umumnya pengajaran modern lebih menitik beratkan pada asas aktivitas. Anak biasanya belajar sambil bekerja.

Sementara itu, Sudjana (2002) menyatakan bahwa aktivitas belajar siswa mencakup dua aspek yang tidak bisa terpisahkan, yakni aktivitas mental (emosional intelektual) dan aktivitas motorik (gerak fisik). Kedua aspek tersebut berkaitan satu sama lain, saling mengisi, dan menentukan. Oleh sebab itu keliru bila seseorang berpendapat bahwa optimalnya cara belajar siswa aktif dilihat dari gerakan motorik dan atau kegiatan mental semata.

Berdasarkan pendapat di atas, peneliti berkesimpulan bahwa aktivitas belajar adalah segala kegiatan yang dilakukan dalam proses interaksi (guru dan siswa) dalam rangka mencapai tujuan belajar. Aktivitas yang dimaksudkan di sini penekanannya adalah pada siswa, sebab dengan adanya aktivitas siswa dalam 
proses pembelajaran terciptalah situasi belajar aktif, seperti yang dikemukakan Depdiknas (dalam Mulyono, 2001) bahwa belajar aktif adalah suatu sistem belajar mengajar yang menekankan keaktifan siswa secara fisik, mental intelektual, dan emosional guna memperoleh hasil belajar yang berupa perpaduan antara aspek kognitif, afektif dan psikomotor.

Dierich (dalam Hamalik, 2001) membagi aktivitas atas 8 kelompok, yaitu kegiatan visual, lisan, pendengaran, menulis, menggambar, metrik, mental dan emosional.

1) Kegiatan-kegiatan visual; meliputi membaca, melihat gambar-gambar, mengamati eksperimen, demontrasi, pameran dan mengamati orang lain bekerja atau bermain.

2) Kegiatan-kegiatan lisan (oral); meliputi mengemukakan suatu fakta atau prinsip, menghubungkan suatu kejadian, mengajukan pertanyaan, memberi saran, mengemukakan pendapat, wawancara, diskusi, interupsi.

3) Kegiatan-kegiatan pendengaran; meliputi mendengarkan penyajian bahan, mendengarkan percakapan atau diskusi kelompok, mendengarkan suatu permainan, mendengarkan radio.

4) Kegiatan-kegiatan menulis; meliputi menulis cerita, menulis laporan, memeriksa karangan, bahan-bahan kopi, membuat rangkuman, mengerjakan tes, dan mengisi angket.

5) Kegiatan-kegiatan menggambar; meliputi menggambar, membuat grafik, chart, diagram peta dan pola.

6) Kegiatan-kegiatan metrik; meliputi melakukan percobaan, memilih alat-alat, melaksanakan pameran, membuat model, menyelenggarakan permainan, menari dan berkebun.

7) Kegiatan-kegiatan mental; meliputi merenungkan, mengingat, memecahkan masalah, menganalisis, melihat hubungan-hubungan, dan membuat keputusan.

8) Kegiatan-kegiatan emosional; meliputi minat, membedakan, berani, tenang, dan lain-lain.

\section{Model Pembelajaran}

Menurut Erman (2008), dalam prakteknya, guru harus ingat bahwa tidak ada model pembelajaran yang paling tepat untuk segala situasi dan kondisi. Oleh karena itu, dalam memilih model pembelajaran yang tepat haruslah memperhatikan kondisi siswa, sifat materi bahan ajar, fasilitas atau media yang tersedia, dan kondisi guru itu sendiri.

Setelah tujuan dan materi dirumuskan, maka dalam proses belajar mengajar, perlu dipertimbangkan model mana yang paling tepat untuk digunakan didalam proses pembelajaran sehingga hasil yang belajar yang diharapakan dapat tercapai. Berkaitan dengan hal ini menurut Enkosworo (dalam Nashihin, 2005) model mengajar adalah bagaimana cara guru mengajar. Dengan demikian dapat disimpulkan bahwa model mengajar atau pembelajaran adalah cara guru di dalam menyampaikan materi secara sistematis untuk mencapai tujuan pengajaran atau pembelajaran yang telah dirumuskan. 
Dalam memilih model pembelajaran perlu diperhatikan beberapa pertimbangan, yaitu: 1) Tujuan yang hendak dicapai, 2) Bahan atau materi pengajaran, 3) Jumlah siswa yang akan menerima pengajaran, 4) Kemampuan guru dan kemampuan siswa, 5) Media/sarana dan prasarana pengajaran yang tersedia, 6) Waktu yang dibutuhkan, dan 7) Keseluruhan situasi bagi berlangsungnya kegiatan belajar mengajar (Malik dalam Nashihin 2005).

Model pembelajaran banyak sekali macamnya. Model pembelajaran yang peneliti gunakan dalam penelitian ini adalah model Talking Stick seperti yang dikemukakan oleh Huri (2008) yaitu model pembelajaran tongkat berbicara. Tahap-tahap pelaksanaannya adalah: 1) Pendahuluan, 2) Kegiatan Inti, dan 3) Penutup. Menurut Liza (2008) kelebihan model Talking Stick ini adalah bahwa model ini mampu:

1) Menguji kesiapan siswa

2) Melatih membaca dan memahami dengan cepat.

3) Menuntut siswa agar lebih giat belajar karena siapa yang bisa menjawab pertanyaan dari pendidik dengan tepat akan mendapatkan poin atau nilai.

4) Membuat siswa lebih berfikir kritis

Penggunaan model mengajar sangat bergantung pada guru sebagai pemegang manajemen kelas dan sekaligus akan menentukan berhasil tidaknya pencapaian tujuan yang hendak dicapai. Menurut S. Nasution (1987) mengajar dan belajar adalah kegiatan guru dan murid untuk mencapai tujuan tertentu. Semakin jelas tujuan semakin jelas kemungkinan-kemungkinannya ditemukan model yang serasi. Namun tidak ada, pegangan yang pasti cara mendapatkan model mengajar yang paling tepat.Tetapi baik tidaknya suatu metode mengajar baru terbukti dari hasil belajar murid. Bila hasil belajar murid tercapai, maka, dianggap telah terjadi proses belajar mengajar yang tepat.

\section{Metode Penelitian}

Penelitian ini tergolong penelitian tindakan kelas. Menurut Arikunto (2006) penelitian tindakan bukan hanya mengetes sebuah perlakuan tetapi lebih dahulu peneliti sudah mempunyai keyakinan akan ampuhnya suatu perlakuan. Selanjutnya dalam penelitian tindakan ini peneliti langsung mencoba dan menerapkan perlakuan tersebut dengan hati-hati seraya mengikuti proses serta dampak perlakuan tersebut.

Penelitian ini dilaksanakan di kelas VIII.2 SMP Negeri 2 Ranah Pesisir Kabupaten Pesisir Selatan pada semester Januari-Juni (semester genap) tahun pelajaran 2012/2013. Penelitian ini juga dilakukan secara kolaboratif dan kooperatif yang anggota kolaborasinya terdiri dari teman sejawat di sekolah tempat peneliti bertugas.

Teknik pengumpulan data dalam penelitian ini dilakukan melalui observasi dengan menggunakan alat pengumpul data dalam bentuk lembar observasi. Dalam penelitian ini data dianalisis secara deskriptif kuantitatif dengan menggunakan format presentase. Untuk mengukur keberhasilan aktifitas belajar siswa dalam pembelajaran maka indikator keberhasilan ditetapkan 60\%. Presentase ini mempedomani kriteria Sudjana (1996), yaitu: 
1) Apabila $\leq 41 \%$ siswa aktif masih perlu dilanjutkan dengan siklus berikutnya;

2) Apabila $\geq 41 \%$ - $\leq 60 \%$ siswa aktif perlu dikonfirmasiakn dengan guru;

3) Apabila $\geq 60 \%$ siswa aktif tindakan dianggap berhasil

\section{Hasil Penelitian dan Pembahasan}

\section{Hasil Penelitian}

Pada bagian ini digambarkan temuan-temuan pada setiap siklus dengan masingmasing siklus terdiri dari empat proses tindakan yaitu: rencana, tindakan, observasi dan refleksi.

\section{Siklus 1}

Pada siklus 1 dilakukan tiga kali proses pembelajaran. Pembelajaran pertama dilakukan pada tanggal 06-02-2013, pembelajaran kedua pada tanggal 11-022013, dan pembelajaran ketiga pada tanggal 18-02-2013. Materi pokok yang disajikan adalah memahami masalah Sistem Perekonomian Indonesia. Kegiatan pembelajaran berlangsung 80 menit untuk satu kali pertemuan (tindakan), yang meliputi:

\section{a. Rencana Tindakan}

Hal-hal yang dilakukan dalam rencana tindakan adalah: 1) Pertemuan dengan guru IPS lainnya sebagai teman sejawat sekaligus teman kolaborasi, untuk mempersiapkan hal-hal yang dirasa perlu pada proses tindakan, 2) Menyiapkan materi yang akan disajikan, 3) Merevisi RPP, 4) Menyiapkan media pembelajaran, 5) Mempersiapkan format observasi, dan 6) Mempersiapkan alat/instrumen evaluasi

\section{b. Pelaksanaan Tindakan}

Pelaksanaan tindakan terdiri dari : 1) pendahuluan, dilakukan selama 15 menit. Pada pendahuluan kegiatan yang dilakukan meliputi; mengobservasi siswa, melakukan apersepsi. 2) kegiatan ini dalakukan selama 45 menit pada tahap ini guru menjelaskan mekanisme metoda Talking Stik kepada siswa untuk memudahkan pelaksanaan tindakan dan memberikan informasi kompetensi yang akan dicapai serta membentuk kelompok yang terdiri dari 4 orang, kemudian masing-masing diberikan bahan ajar. Pada KB I materi ajarnya adalah Mendeskripsikan arti sistem perekonomian dan macam-macamnya dan Mengidentifikasi kebaikan dan kelemahan macam-macam sistem ekonomi. Pada KB II meterinya adalah mengidentifikasi ciri-ciri perekonomian Indonesia dan Mengidentifikasi kebaikan dan kelemahan sistem perekonomian Indonesia. Sedangkan pada KB III membahas materi tentang pengertian pajak dan retribusi dan mengidentifikasikan sifat, penetapan tarif pajak, dan membedakan pajak langsung dan pajak tidak langsung beserta contohnya.

Pada langkah berikutnya : (a) siswa membaca materi dan masing-masing membuat rangkuman dibuku catatan; (b) siswa melakukan Tanya jawab dalam 
kelompok tentang inti sari (rangkuman) materi yang telah mereka baca dan membuat rangkuman untuk kelompok; (c) guru menyuruh beberapa kelompok untuk mempresentasikan hasil diskusi mereka, sedangkan kelompok lain diminta untuk memberikan tanggapan dan juga sanggahan; (d) semua kegiatan diskusi antar kelompok ini dimoderatori oleh guru. 3) Penutup (20 menit), pada kegiatan penutup dilakukan: (a) guru bersama siswa menyipulkan materi, (b) guru melakukan evaluasi, (c) guru memberikan tugas di rumah untuk siswa pada pertemuan berikutnya.

\section{c. Observasi}

Pengamatan pada siklus pertama dilakukan untuk tiga kali pertemuan, sesuai materi yang diajarkan. Hasil pengamatan selama pembelajaran pada siklus pertama diperoleh data tentang aktivitas dan hasil belajar siswa melalui lembar observasi yang dicatat oleh observer. Sedangkan data hasil belajar diperoleh atau diambil dari nilai UH pada setiap akhir siklus.

Aktivitas siswa yang diamati meliputi aktivitas mendengarkan waktu guru menerangkan, aktivitas membaca ketika diberi kesempatan membaca, aktivitas mengacungkan tangan saat guru memberi pertanyaan, aktivitas memberikan jawaban ketika guru memberikan pertanyaan, aktivitas memberikan pendapat ketika diberi kesempatan mengeluarkan pendapat, dan aktivitas bertanya ketika diberi kesempatan bertanya. Data yang diperoleh dicatat dan dipersentasekan. Pada waktu observasi aktivitas siswa terlihat masih rendah, seperti dapat dilihat pada Tabel 1 sebelumnya. Untuk itu peneliti menggunakan model pembelajaran Talking Stick untuk melihat apakah ada peningkatan aktivitas belajar siswa dengan menggunakan model ini. Data mengenai aktivitas belajar siswa selama proses pembelajaran pada siklus pertama dapat dilihat pada Tabel 2 berikut ini:

Tabel 2: Hasil Observasi Aktivitas Belajar Siswa Pada Siklus 1

\begin{tabular}{|c|c|c|c|c|c|c|c|c|c|c|c|c|}
\hline \multirow{2}{*}{$\begin{array}{l}\text { Perte } \\
\text { muan }\end{array}$} & \multicolumn{2}{|c|}{ Mendengar } & \multicolumn{2}{|c|}{ Membaca } & \multicolumn{2}{|c|}{$\begin{array}{l}\text { Mengacung- } \\
\text { kan Tangan }\end{array}$} & \multicolumn{2}{|c|}{$\begin{array}{l}\text { Memberi- } \\
\text { kan } \\
\text { Jawaban }\end{array}$} & \multicolumn{2}{|c|}{$\begin{array}{l}\text { Memberi- } \\
\text { kan } \\
\text { Pendapat }\end{array}$} & \multicolumn{2}{|c|}{ Bertanya } \\
\hline & $\begin{array}{l}\text { Siswa } \\
\text { Aktif }\end{array}$ & $\%$ & $\begin{array}{l}\text { Siswa } \\
\text { aktif }\end{array}$ & $\%$ & $\begin{array}{l}\text { Siswa } \\
\text { aktif }\end{array}$ & $\%$ & $\begin{array}{l}\text { Siswa } \\
\text { aktif }\end{array}$ & $\%$ & $\begin{array}{l}\text { Siswa } \\
\text { aktif }\end{array}$ & $\%$ & $\begin{array}{l}\text { Siswa } \\
\text { aktif }\end{array}$ & $\%$ \\
\hline 1. & 18 & 53 & 17 & 50 & 14 & 41,2 & 12 & 35,2 & 6 & 17,6 & 8 & 23,5 \\
\hline 2. & 23 & 67,6 & 24 & 70,5 & 14 & 41,2 & 14 & 41,2 & 7 & 20,5 & 9 & 26,5 \\
\hline 3. & 25 & 73,5 & 26 & 76,5 & 17 & 50 & 16 & 47 & 9 & 26,5 & 11 & 32,3 \\
\hline Jumlah & 66 & - & 67 & - & 45 & - & 42 & - & 22 & - & 28 & - \\
\hline $\begin{array}{l}\text { Rata- } \\
\text { rata }\end{array}$ & & 64,7 & & 65,6 & & 44,2 & & 41,1 & & 21,5 & & 27,4 \\
\hline
\end{tabular}

Sumber: Pengolahan data primer

Berdasarkan Tabel 2 dapat dilihat bahwa: (1) rata-rata siswa yang aktif mendengar pada siklus 1 adalah sebanyak $64,7 \%$, (2) rata-rata siswa yang aktif membaca sebanyak $65,6 \%$, (3) rata-rata siswa yang aktif mengacungkan tangan sebanyak $44,2 \%$, (4) rata-rata siswa yang aktif memberikan jawaban sebanyak 41,1\%, (5) 
rata-rata siswa yang aktif memberikan pendapat sebanyak 21,5\%, dan (6) rata-rata siswa yang aktif bertanya sebanyak $27,4 \%$.

\section{Siklus 2}

Pelaksanaan kegiatan pembelajaran pada siklus 2 ini juga dilakukan tiga kali pertemuan. Pembelajaran pertama dilakukan pada tanggal 04-03-2013. Pada kegiatan belajar (KB) 1 ini, materi yang diajarkan adalah mengidentifikasi fungsi dan peranan pajak dalam kehidupan suatu Negara, jenis pajak yang ditanggung oleh keluarga dan sanksi terhadap wajib pajak yang melalaikannya. Pembelajaran kedua dilaksanakan pada tanggal 11-03-2013. Pada KB 2 ini, materi yang diajarkan berkaitan dengan pengertian dan fakta yang mempengaruhi permintaan barang dan jasa, hubungan antara permintaan barang/jasa dengan harga barang/jasa tersebut, dan hukum permintaan. Sedangkan pembelajaran ketiga dilaksanakan pada tanggal 18-03-2013 dengan materi tentang pemberlakuan hukum permintaan, pengertian dan faktor yang mempengaruhi penawaran barang/jasa, keterkaitan antara penawaran dengan harga barang yang ditawarkan dan kurva penawaran.

Kegiatan yang dilaksanakan pada siklus 2 dapat digambarkan secara ringkas sebagai berikut.

a. Rencana Tindakan

Ada beberapa upaya pendekatan yang dilakukan sebelum pembelajaran pada siklus 2 ini dilakukan (sama halnya dengan kegiatan siklus 1) yaitu: 1) Interaksi dengan guru mata pelajaran sejenis, khususnya rekan kolaborasi terkait dengan rencana yang perlu dilakukan pada awal siklus kedua, 2) Menyepakati metoda Talking Stick yang akan dilakukan lebih didintensifkan pelaksanaannya agar siswa betul- betul dapat melaksanakan dengan baik sesuai dengan kriterianya, 3) Merevisi RPP, 4) Mempersiapkan bahan ajar, 5) Menyiapkan perangkat penilaian, dan 6) Menyiapkan format obsevasi.

\section{b. Pelaksanaan Tindakan}

Pelaksanaan tindakan pembelajaran dalam siklus 2 ini juga dilakukan selama 80 menit dengan tiga tahapan tindakan yaitu: 1) Pendahuluan, dilakukan selama 15 menit, kegiatan mencakup; observasi siswa, apersepsi memotivasi siswa. Guru juga kembali menjelaskan mekanisme pelaksanaan metoda Talking Stick kepada siswa, 2) Kegiatan inti dilakukan dilakukan selama 45 menit, pada tahap ini guru menginformasikan tentang kompetensi yang akan dicapai pada akhir kegiatan pembelajaran, pada langkah berikutnya, 3) Penutup dilakukan selama 20 menit, mencakup tindakan seperti pada siklus 1, yaitu: (a) Guru bersama siswa membuat kesimpulan dari materi yang telah dibahas; (b) Guru melakukan evaluasi, untuk mengetahui hasil belajar siswa; dan (3) Guru memberikan tugas di rumah untuk siswa pada pertemuan berikutnya. 


\section{c. Observasi}

Setelah dilaksanakan tindakan pada siklus 2 ini secara lebih intensif dari siklus 1 yang meliputi aspek membaca, bertanya, menjawab, menyanggah, dan menyimpulkan, serta memperbaiki kualitas catatan siswa, maka hasil pengamatannya dapat dilihat pada Tabel 3 berikut ini.

Tabel 3: Hasil Observasi Aktivitas siswa pada Siklus 2

\begin{tabular}{|c|c|c|c|c|c|c|c|c|c|c|c|c|}
\hline \multirow{2}{*}{$\begin{array}{l}\text { Perte } \\
\text { muan }\end{array}$} & \multicolumn{2}{|c|}{ Mendengar } & \multicolumn{2}{|c|}{ Membaca } & \multicolumn{2}{|c|}{$\begin{array}{l}\text { Mengacung- } \\
\text { kan Tangan }\end{array}$} & \multicolumn{2}{|c|}{$\begin{array}{c}\text { Memberi- } \\
\text { kan } \\
\text { Jawaban }\end{array}$} & \multicolumn{2}{|c|}{$\begin{array}{l}\text { Memberi- } \\
\text { kan } \\
\text { Pendapat }\end{array}$} & \multicolumn{2}{|c|}{ Bertanya } \\
\hline & $\begin{array}{l}\text { Siswa } \\
\text { Aktif }\end{array}$ & $\%$ & $\begin{array}{l}\text { Siswa } \\
\text { aktif }\end{array}$ & $\%$ & $\begin{array}{l}\text { Siswa } \\
\text { aktif }\end{array}$ & $\%$ & $\begin{array}{l}\text { Siswa } \\
\text { aktif }\end{array}$ & $\%$ & $\begin{array}{l}\text { Siswa } \\
\text { aktif }\end{array}$ & $\%$ & $\begin{array}{l}\text { Siswa } \\
\text { aktif }\end{array}$ & $\%$ \\
\hline 1. & 23 & 67,6 & 22 & 64,7 & 18 & 52,9 & 14 & 41,2 & 12 & 35,3 & 12 & 35,3 \\
\hline 2. & 26 & 76,5 & 25 & 73,5 & 22 & 64,7 & 17 & 50 & 12 & 35,3 & 14 & 41,2 \\
\hline 3. & 25 & 73,5 & 27 & 79,4 & 20 & 58,8 & 19 & 55,8 & 15 & 44,2 & 12 & 38,2 \\
\hline Jumlah & 74 & & 74 & & 60 & & 50 & & 39 & & 38 & \\
\hline $\begin{array}{l}\text { Rata- } \\
\text { rata }\end{array}$ & & 72,5 & & 72,5 & & 58,6 & & 49 & & 38,2 & & 38,2 \\
\hline
\end{tabular}

Sumber: Pengolahan data primer

Berdasarkan Tabel 3 dapat diperhatikan bahwa: (1) rata-rata siswa yang aktif mendengar pada siklus II adalah sebanyak $72,5 \%$, (2) rata-rata siswa yang aktif membaca sebanyak $72,5 \%$, (3) rata-rata siswa yang aktif mengacungkan tangan sebanyak 58,6 \%, (4) rata-rata siswa yang aktif memberikan jawaban sebanyak $49 \%$ (5) rata-rata siswa yang aktif memberikan pendapat sebanyak 38,2\% (6) ratarata siswa yang aktif bertanya sebanyak $38,2 \%$.

Selanjutnya peningkatan aktivitas siswa pada siklus 1 dan siklus 2 dapat pula dilihat pada Tabel 4 berikut:

Tabel 4. Perbandingan Peningkatan Aktivitas Siswa Pada Siklus 1 dan 2

\begin{tabular}{clccc}
\hline No. & \multicolumn{1}{c}{ Aktivitas Siswa } & $\begin{array}{c}\text { Siklus 1 } \\
(\mathbf{\%})\end{array}$ & $\begin{array}{c}\text { Siklus 2 } \\
(\mathbf{\%})\end{array}$ & $\begin{array}{c}\text { Peningkatan } \\
(\mathbf{\%})\end{array}$ \\
\hline 1. & $\begin{array}{l}\text { Aktivitas mendengarkan waktu guru } \\
\text { menerangkan }\end{array}$ & 64,7 & 72,5 & 7,8 \\
2. & $\begin{array}{l}\text { Aktivitas membaca ketika diberi } \\
\text { kesempatan membaca }\end{array}$ & 65,6 & 72,5 & 7,0 \\
3. & $\begin{array}{l}\text { Aktivitas mengacungkan tangan saat guru } \\
\text { memberi pertanyaan }\end{array}$ & 44,2 & 58,6 & 14,4 \\
4. & $\begin{array}{l}\text { Aktivitas memberikan jawaban ketika guru } \\
\text { memberikan pertanyaan }\end{array}$ & 41,1 & 49 & 7,9 \\
5. $\begin{array}{l}\text { Aktivitas memberikan pendapat ketika } \\
\text { diberi kesempatan mengeluarkan pendapat }\end{array}$ & 21,5 & 38,2 & 16,7 \\
6. & $\begin{array}{l}\text { Aktivitas bertanya ketika diberi kesempatan } \\
\text { bertanya }\end{array}$ & 27,4 & 38,2 & 10,8 \\
\hline & Rata-rata aktivitas siswa & $\mathbf{4 4 , 1}$ & $\mathbf{5 4 , 8}$ & $\mathbf{1 0 , 8}$ \\
\hline
\end{tabular}

Sumber: Pengolahan data primer 
Dari pengamatan peneliti dan observer pada pertemuan pertama sampai terakhir pada siklus 2 ini, pelaksanaan penelitian pada umumnya sudah berjalan seperti yang diharapkan. Hal ini disebabkan karena siswa telah terbiasa dengan model pembelajaran yang sudah diterapkan. Dari tes yang didapat pada siklus 2 ini, aktivitas siswa sudah semakin menunjukkan peningkatan. Karena aktivitas belajar siswa sudah meningkat sesuai dengan yang diharapkan, maka peneliti mencukupkan dan menghentikan penelitian pada siklus 2 ini.

\section{Pembahasan}

Penelitian tindakan kelas ini dilaksanakan dengan bersiklus yang terdiri dari dua siklus. Siklus pertama telah direncanakan, namun hasil observasi dan refleksi menunjukkan siklus pertama belum menunjukkan hasil yang belum memuaskan. Hal ini terlihat dari ada beberapa aktivitas siswa yang belum mencapai hasil yang memuaskan yaitu aktivitas bertanya, aktivitas ketika diberi kesempatan bertanya dan aktivitas memberikan pendapat ketika diberi kesempatan mengeluarkan pendapat. Selain itu nilai hasil belajar siswa juga belum mencapai target, yaitu target pada siklus 1 . Hal ini disebabkan siswa masih agak bingung dengan model pembelajaran ini. Bertolak dari kondisi di atas maka peneliti melanjutkan siklus kedua dengan merencanakan tindakan dengan cara: (1) memberikan bahan yang akan dipelajarai siswa pada pertemuan selanjutnya, (2) memberikan tambahan poin dan hadiah pada akhir pembelajaran terhadap siswa yang aktif. Dari hasil observasi dan refleksi pada siklus kedua yang terdiri dari 3 kali pertemuan menunjukkan peningkatan aktivitas siswa yang signifikan. Dengan demikian tindakan dihentikan pada siklus kedua atau tidak dilanjutkan pada siklus ketiga.

Dari penjelasan di atas terlihat bahwa penerapan model Talking Stick ternyata mampu meningkatkan aktivitas belajar siswa dalam mata pelajaran IPS pada siswa Kelas VIII.2 SMPN 02 Ranah Pesisir Kabupaten Pesisir Selatan. Temuan penelitian ini berarti memperkuat pendapat yang dikemukakan oleh Liza (2008) yang menyatakan bahwa di antara kelebihan model Talking Stick adalah bahwa model ini mampu menuntut siswa agar lebih giat beraktifitas dalam belajar karena siapa yang bisa menjawab pertanyaan dari pendidik dengan tepat akan mendapatkan poin atau nilai. Disamping itu itu model ini juga dapat membuat siswa mampu lebih berfikir kritis. Berdasarkan pembahasan ini terlihat dengan jelas bahwa pelaksanaan metoda dan model pembelajaran Talking Stick dapat mendorong meningkatnya aktifitas belajar siswa dalam pembelajaran, terutama dalam pembelajaran IPS.

\section{Penutup}

Berdasarkan hasil penelitian dan pembahasan pada bab sebelumnya maka dapat diambil beberapa kesimpulan bahwa pendekatan pembelajaran dengan menggunakan model Talking Stick mampu meningkatkan aktivitas belajar siswa dalam mata pelajaran IPS siswa Kelas VIII.2 SMPN 02 Ranah Pesisir Kabupaten Pesisir Selatan, baik dalam aktivitas mendengarkan maupun aktivitas membaca, mengacungkan tangan, memberikan jawaban, memberikan pendapat dan bertanya. 
Dengan demikian, berdasarkan kesimpulan dalam penelitian ini, dalam penelitian dapat dikemukakan saran-saran sebagai berikut:

1) Bagi guru IPS SMPN 02 Ranah Pesisir Kabupaten Pesisir Selatan khususnya, dan guru IPS pada umumnya diharapkan dapat menggunakan pendekatan pembelajaran IPS dengan menggunakan model pembelajaran Talking Stick,

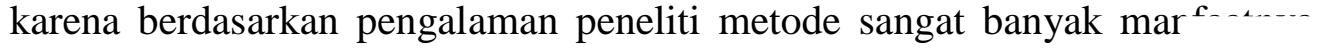
dalam meningkatkan aktifitas belajar siswa, dan sudah barang tentu 1 berdampak positif pada peningkatan hasil belajar siswa.

2) Bagi peneliti yang berminat diharapkan dapat melanjutkan peneli dengan pokok bahasan yang berbeda dan pada mata pelajaran yang pula.

\section{DAFTAR KEPUSTAKAAN}

Arikunto, S. dkk. 1989. Prosedur Penelitian Suatu Pengantar. Yogyakarta: Rineka Cipta.

Arikunto, S. 2006. Prosedur Penelitian Suatu Pendekatan Praktis. Jakarta: Rineka Cipta.

Erman. 2008. "Model Belajar dan Pembelajaran Berorientasi Kompetensi Siswa". Diakses dari http://educare.efkipunla.net/index2.php?option=comcontent \&do_pdf--I\&id=60

Hamalik, Oemar. 2001. Proses Belajar Mengajar. Jakarta: Bumi Aksara.

Huri, Lukman. 2008. "Rencana Program Pembelajaran Mata Pelajaran Geografi". Diakses dari www.smaneka.sch.id.

Liza. 2008. "Belajar dan Game, Kurangi Kebosanan Siswa di Kelas”. Diakses dari http://talkingstik. com.pembelajaran inovatif.

Mulyono. 200I. Macam-macam Aktivitas Belajar. Diakses dari http//aktivitas belajar.com/educare.

Nashihin, Hudan. 2005. Implementasi Metode Berprograma, Penemuan dan Ceramah Pada Siswa Kelas I SMU I Temun Kulon Progo. Yogyakarta: UIN sunan Kalijaga

Nasution, S. 1987. Teknologi Pendidikan. Jakarta: Bumi Aksara

Sudjana, Nana. 2002. Cara Belajar Murid Aktif. Bangung: Sinar Baru Algenso.

Sudjana. 1996. Metode Statistika. Bangung: Tarsito. 